\title{
DAMPAK DARI PENETAPAN UU NOMOR 26 TAHUN 2000 TERHADAP KEJAHATAN KEMANUSIAAN DAN GENOSIDA DI INDONESIA
}

\author{
Oleh: \\ Anwar Hafidzi \\ Email: anwar.hafidzi@gmail.com \\ Dosen Hukum Keluarga Fakultas Syariah dan Ekonomi Islam \\ Institut Agama Islam Negeri Antasari Banjarmasin
}

\begin{abstract}
Until now several media in Indonesia is still preaching about violence in the name of religion, the burning of places of worship, Lapindo victims are still homeless, and many more events that involve the community in large numbers. Every human being has the right to live, but whether the appropriate law enforcement or still need improvement. This brief article will look at the impact of Law Number 26 on 2000 regarding Human Rights Court and its relevance to law enforcement. With the enactment of this Act, at least provides an opportunity to take back the cases of gross human rights violations that had occurred before the article appeared 43,44,46 of the Ad-hoc human rights court. Of course in the end, it is required for the support of law enforcement officials, political influence and a role of the community to criminalize of human rights although it is still the absence of explicit provisions in its implementation.
\end{abstract}

Abstrak: Sampai saat ini beberapa media di Indonesia masih ada yang memberitakan mengenai kekerasan dengan mengatasnamakan Agama, pembakaran tempat ibadah, korban lapindo yang masih ada tidak memiliki tempat tinggal, dan masih banyak lagi kejadian yang melibatkan komunitas dalam jumlah besar. Pada dasarnya, setiap manusia memiliki hak dalam hidupnya, tapi apakah penegakkan hukumnya sesuai atau masih perlu pembenahan. Tulisan singkat ini akan melihat dampak dari UU Nomor 26 Tahun 2000 mengenai Pengadilan Hak Asasi Manusia dan relevansinya pada penegakkan hukum. Dengan diundangkannya UU ini, setidaknya memberikan kesempatan untuk mengangkat kembali kasus tentang pelanggaran HAM berat yang pernah terjadi sebelum muncul pasal 43,44,46 tentang pengadilan HAM Ad-Hoc. Tentu pada akhirnya diperlukan dukungan dari para penegak hukum, pengaruh politik dan peran masyarakat untuk mengadili terhdap kriminalisasi HAM meskipun masih yang tidak adanya ketentuan yang jelas dalam pelaksanaannya.

\section{Kata Kunci: Diskriminasi, Islam, hukum, kejahatan}

\section{Pendahuluan}

Pada saat ini perkembangan peradilan dan pengadilan Hak Asasi Manusia (HAM) tidak terlepas dari pemahaman terhadap hukum pidana, yang merupakan sebuah gambaran hukum yang banyak berkaitan dengan pengaturan tentang kejahatan.

Orde baru yang berkuasa selama 33 tahun (1965-1998) telah banyak dicatat melakukan pelanggaran-pelanggaran HAM. Orde baru yang memerintah secara otoriter selama lebih dari 30 tahun telah melakukan berbagai tindakan pelanggaran HAM karena perilaku negara dan aparatnya. Komisi Nasional Hak Asasi Manusia (Komnas HAM) dalam laporan tahunnya menyatakan bahwa pemerintah perlu menuntaskan segala bentuk pelanggaran HAM yang pernah terjadi di tanah air sebagai akibat dari struktur kekuasaan orde baru yang otoriter. ${ }^{1}$

Asvi Warman Adam seperti yang dikutip oleh Sivfian dan Sumartono yang menggolongkan ada sepuluh pelanggaran HAM berat dalam periode 1945-1998 yang meliputi: 1) Ekses Demokrasi Terpimpin (antara lain penahanan tokoh Masyumi/ PSI tanpa diadili); 2) Pembantaian 1965/1966; 3) Penahanan politik di kamp Pulau Buru (1969-1979); 4) Kasus Timor-Timur (serangan 7 Desember 1975); 5)Kasus Aceh; 6) Kasus Irian Jaya; 7) Penembak Misterius (Petrus); 8) Kasus Tanjung

\footnotetext{
1 Abidin,Zainal,Pengadilan Hak Asasi Manusia di Indonesia: Kursus HAM untuk pengacara XI tahun 2007. Lembaga Studi dan Advokasi Masyarakat. www.elsam. or.id.
} 
Priok 1984; 9) 27 Juli 1996; 10) Seputar kerusuhan Mei 1998. Dari sepuluh kategori itu hanya ada satu yang pada masa orde lama. ${ }^{2}$

Selanjutnya, setelah orde baru maka banyak bermunculan pelanggaran HAM dalam bentuk aksi kekerasan massa, konflik antar etnis yang banyak menelan korban jiwa dan pembumihangusan di Timor-timur. Lembaga Studi dan Advokasi Masyarakat (ELSAM) juga pernah menyebutkan pada triwulan pertama 1998 telah terjadi 1.629 pelanggaran HAM yang fundamental yang tergolong ke dalam hak-hak yang tak dapat dikurangi dari 12 propinsi yang pada akhirnya dapat menjadi sumber data. ${ }^{3}$ Hak-hak tersebut diantaranya adalah hak manusia atas kehidupannya, hak untuk mendapatkan kebebasan dari penyiksaan, hak terlepas dari penangkapan sewenang-wenang, hak terbebas dari pemusnahan seketika, dan hak terlepas dari penghilangan paksa.

Deklarasi universal hak-hak asasi manusia oleh sidang umurm perserikatan bangsa-bangsa (PBB), 10 Desember $1948^{4}$,yang dikenal dengan sebutan "Universal Declaration of Human Right" merupakan suatu peristiwa penting dan keadaan ini mempunyai nilai historis yang sangat besar. Hal ini memang merupakan sebuah hal yang sangat bernilai positif dalam menghargai dan menjaga hak-hak asasi dan kebebasan fundamental bagi manusia. Kesepakatan ini merupakan angin segar bagi dunia internasional namun akan menjadi tergerus jika menggunakan dengan semena-mena. Hal ini yang memunculkan perbedaan yang sangat mendasar antara HAM dalam Barat dan Islam, meski memiliki tujuan yang sama, akan tetapi memiliki proses yang berbeda. Keadaan ini menjadi pertanda akan majunya pemikiran dan pendidikan hukum masyarakat demi perjuangan hak manusia saat ini.

\footnotetext{
2 Sivfian Hendra Legowo, IG.Krisnadi, Hendro Sumartono, "Dinamika Politik Rezim Orde Baru di Indonesia Studi Tentang Kegagalan Konsolidasi Politik Rezim Orde Baru Tahun 1990-1996". Jurnal Publika Budaya Voluime 1 November 2013 Universitas Jember. h. 16-24.

3 Arsip Kompas,15 April 1998 (accessed at www.elsam. or.id, 7 December 2015)

4 Timur.M. Hak asasi manusia dalam Islam, sebuah dialog tentang Islam dan hak-hak asasi manusia. Yayasan Obor Indonesia, Jakarta 1987.h. 75-78.

Lih. Juga Abdulla Rozali, Perkembangan HAM dan Keberadaan Pengadilan HAM di Indonesia, Ghalia Indonesia, Jakarta, h. 2.
}

\section{Kompetensi Pengadilan Hak Asasi Manusia}

Kata "hak" dapat diidentifikasikan dalam berbagai kamus sebagai tuntutan yang pantas untuk diberikan. Sehingga dapat diartikan bahwa manusia memiliki hak yang pantas untuk mendapatkan perlakuan dan keadilan yang sesuai dalam kehidupan sosial. ${ }^{5}$ Pengertian ini memberikan makna bahwa hak asasi manusia itu merupakan hak-hak dasar dan juga merupakan anugerah dari Tuhan yang Maha Esa. Maka dapat dipahami secara mendasar, bahwa hak asasi manusia tersebut tidaklah bersumber dari negara dan hukum, tetapi semata-mata bersumber dari Tuhan sebagai pencipta alam dan seisinya, jika tanpa kuasa Tuhan maka mustahil manusia dapat hidup secara hakiki dan bermartabat. Oleh karena itu yang diperlukan dari negara dan hukum adalah suatu pengakuan dan jaminan perlindungan terhadap hak asasi manusia tersebut kepada seluruh lapisan masyarakat.

Perjuangan yang dilakukan untuk memperoleh pengakuan dan jaminan terhadap hak asasi manusia, sepanjang sejarah umat manusia selalu mengalami pergolakan yang tidak pernah terhenti. Puncak keberhasilan perjuangan untuk memperoleh pengakuan dan jaminan perlindungan terhadap hak asasi manusia, ditunjukkan dengan munculnya kesepakatan dengan nama Piagam Perserikatan Bangsa-Bangsa mengenai hak asasi manusia. Keberadaan Piagam tersebut pada akhirnya permasalahan hak asasi menjadi pioner dipenjuru belahan dunia, telebih lagi jika berada di negaranegara maju.

Sesudah perang dingin arus gelombang hak asasi manusia semakin deras melanda seantero dunia, malah kadang-kadang negara-negara Barat terkesan ingin memaksakan penerapan konsep hak asasi manusia menurut pandangan mereka kepada negara-negara lain, tanpa memperhatikan keanekaragaman tata nilai, sejarah, kebudayaan sistem politik, tingkat pertumbuhan sosial dan ekonomi serta faktor-faktor lain yang dimiliki bangsa yang bersangkutan. ${ }^{6}$ Padahal sebenarnya hak asasi manusia sebagai suatu prinsip memang ${ }^{5}$ Sukron Kamil, dkk,"Syariah Islam dan HAM", Center for the Study of Religion and Culture (CSRC) Universitas Islam Negeri Syarif Hidayatullah Jakarta.2007.h.1.

Lih. Juga Tim ICCE, "Pendidikan Kewarganegaraan: Demokrasi, HAM, dan Masyarakat Madani”, Jakarta, 2003.h. 200-201.

"Sukron Kamil, dkk,"Syariah Islam dan HAM", Center for the Study of Religion and Culture (CSRC) Universitas Islam Negeri Syarif Hidayatullah Jakarta.2007.h.3. 
bersifat universal dalam arti dimana saja dan kapan saja harus tetap sama. Namun, sebagai suatu sistem nilai keanekaragaman tata nilai, sejarah, kebudayaan, sistem politik, tingkat pertumbuhan sosial dan ekonomi, serta faktor-faktor lain yang dimiliki oleh bersangkutan. Jadi tidak mungkin konsep hak asasi manusia menurut pandangan Barat dipaksakan berlaku bagi negara lain, karena pemaksaan tersebut justru merupakan pelanggaran terhadap Hak Asasi Manusia itu sendiri.

Sebagai contoh dapat dikemukakan disini, dua pasal dari Universal Declaration of Human Right, yaitu sebgai berikut.

1. Pasal 16 Ayat (1) menyebutkan bahwa seorang laki-laki dan seorang wanita bebas melakukan perkawinan, tanpa dibatasi oleh suku, bangsa dan agama.

2. Pasal 18 menyebutkan bahwa setiap orang bebas untuk memeluk dan keluar dari suatu agama.

Penerapan kedua pasal ini bagi masyarakat yang beragama Islam tanpa memperhatikan nilai-nilai ajaran Islam yang dianutnya akan bisa menimbulkan masalah, karena menurut keyakinan sebagian umat Islam seorang Muslim dilarang kawin dengan seorang non-Muslim, dan perbuatan keluar dari agama Islam adalah murtaad dan merupakan dosa besar. ${ }^{7}$ Masalah ini sebenarnya sampai sekarang masih menimbulkan suatu polemik dikalangan umat Islam sendiri. Karena ketidak sesuaian antara hak asasi sebagai manusia dan hak terhadap agama Islam.

Isu-isu mengenai hak asasi manusia dewasa ini bukan lagi berkisar seputar masalah pengakuan dan jaminan perlindungan terhadap hak asasi manusia. Karena hampir seluruh negara-negara maju telah mengatur baik dalam konstitusinya maupun dalam undang-undang negara. Akan tetapi sekarang tertuju pada isu-isu penegakan terhadap kejahatan manusia, suku dan pemajuan hak asasi manusia itu sendiri.

\section{Hak Asasi Manusia Dalam Syariat Islam}

Hak asasi manusia (HAM) adalah hak-hak yang dipunyai oleh semua orang sesuai dengan kondisi yang manusiawi. Hak asasi manusia ini selalu dipandang sebagai sesuatu yang mendasar, fundamental dan penting. Oleh karena itu, banyak 7 Abdulla Rozali, "Perkembangan HAM dan Keberadaan Pengadilan HAM di Indonesia", Ghalia Indonesia, Jakarta, h.11. pendapat yang mengatakan bahwa hak asasi manusia itu adalah "kekuasaan dan keamanan" yang dimiliki oleh setiap individu. ${ }^{8}$

Adapun mengenai Ide HAM sendiri juga terdapat dalam Islam, yang telah tertuang dalam syari'ah sejak diturunkannya Islam. Hal ini dapat dilihat dalam ajaran tauhid. Tauhid dalam islam mengandung arti bahwa hanya ada satu pencipta bagi alam semesta. Ajaran dasar pertama dalam Islam adalah la ilaha illa Allah (tiada Tuhan selain Allah SWT). Seluruh alam dan semua yang ada dipermukaan bumi adalah ciptaan Allah, semua manusia, hewan, tumbuhan dan benda takbernyawa berasal dari Allah.

Dengan demikian, dalam tauhid terkandung ide persamaan dan persaudaraan seluruh manusia. ${ }^{9}$ Dari ajaran dasar persamaan dan persaudaraan manusia tersebut, timbullah kebebasan-kebebasan manusia, seperti kebebasan dari perbudakan, kebebasan beragama, kebebasan mengeluarkan pendapat dan lain-lain. Dari situ pulalah timbul hakhak asasi manusia, seperti hak hidup, hak memiliki harta, hak berbicara, hak berpikir dan sebagainya.

\section{Konsep HAM dalam Islam}

Hak asasi manusia dalam Islam tertuang secara transenden untuk kepentingan manusia, lewat syari'ah Islam yang diturunkan melalui wahyu. Menurut syari'ah, manusia adalah makhluk bebas yang mempunyai tugas dan tanggung jawab, dan karenanya ia juga mempunyai hak dan kebebasan. Dasarnya adalah keadilan yang ditegakkan atas dasar persamaan atau egaliter, tanpa pandang bulu. Artinya, tugas yang diemban tidak akan terwujud tanpa adanya kebebasan,sementara kebebasan secara eksistensial tidak terwujud tanpa adanya tanggung jawab itu sendiri. Sistem HAM Islam mengandung prinsip-prinsip dasar tentang persamaan, kebebasan dan penghormatan terhadap sesama manusia. 8 dalam konsep persamaan ini, artinya Islam memandang semua manusia sama dan mempunyai kedudukan yang sama, satu-satunya keunggulan yang dinikmati seorang manusia atas manusia lainya hanya ditentukan oleh tingkat ketakwaannya. Hal ini sesuai dengan firman Allah dalam Surat Al-Hujarat ayat 13, mengenai konsep , yang artinya sebagai berikut :

8 Harun Nasution dan Bahtiar Effendi (ed), Hak Asasi Manusia dalam Islam, Yayasan Obor Indonesia, Jakarta, 1987. h.14.

9 Harun Nasution dan Bahtiar Effendi (ed), Hak Asasi Manusia dalam Islam. h.18. 
"Hai manusia, sesungguhnya Kami ciptakan kamu dari laki-laki dan perempuan, dan Kami jadikan kamu berbangsa-bangsa dan bersuku-suku agar kamu saling mengenal.Sesungguhnya yang paling mulia di antara kaum adalah yang paling takwa."

Sedangkan kebebasan merupakan elemen penting dari ajaran Islam. Kehadiran Islam memberikan jaminan pada kebebasan manusia agar terhindar dari kesia-siaan dan tekanan, baik yang berkaitan dengan masalah agama, politik dan ideologi. Namun demikian, pemberian kebebasan terhadap manusia bukan berarti mereka dapat menggunakan kebebasan tersebut mutlak, tetapi dalam kebebasan tersebut terkandung hak dan kepentingan orang lain yang harus dihormati juga.

Mengenai penghormatan terhadap sesama manusia, dalam Islam seluruh ras kebangsaan mendapat kehormatan yang sama. Semua adalah keturunan Adam, jika Adam tercipta dari tanah, dan mendapat kehormatan di sisi Allah, maka seluruh anak cucunya pun mendapatkan kehormatan yang sama, tanpa terkecuali.

Pada dasarnya HAM dalam Islam terpusat pada lima hal pokok yang terangkum dalam konsep Imam Al-Syathiby al-dloruriyat al-khomsah atau yang disebut juga al-huquq al-insaniyah fi al-islam (hak-hak asasi manusia dalam Islam). Konsep ini mengandung lima hal pokok yang harus dijaga oleh setiap individu, yaitu :

1. Hifdzu al-din (penghormatan atas kebebasan beragama),

2. Hifdzu al-mal (penghormatan atas harta benda),

3. Hifdzu al-'aql (penghormatan atas kebebasan berpikir)

4. Hifdzu al- nasl (keharusan untuk menjaga keturunan).

5. Hifdzu al-nafs wa al-'ird (penghormatan atas jiwa, hak hidup dan kehormatan individu). ${ }^{10}$

Kelima hal pokok inilah yang harus dijaga oleh setiap umat Islam supaya menghasilkan tatanan kehidupan yang lebih manusiawi, berdasarkan atas penghormatan individu atas individu, individu dengan masyarakat, masyarakat dengan masyarakat, masyarakat dengan negara dan komunitas agama dengan komunitas agama lainnya.

\footnotetext{
${ }^{10}$ Ali Ibn al-Ka $>$ fi $>$ al-Subki $>$, Al-Ibha $>$ j syarh al-Minha $>$ j fi $>$ 'Ilmil al-Ushul lil Baidhawi>, Da>rul al-Kutub al'Ilmiyah, Beirut, cet. 1. 1404 H. Vol.3.h.178.
}

HAM yang dijamin oleh Islam seperti yang diatur dalam al-Qur'an sebagai sumber dan dasar ajaran Islam bagi manusia. HAM dasar terdapat dalam al-Quran terdiri dari :

a) Hak atas keselamatan jiwa. Dalam Islam jiwa seseorang sangat dihormati dan keberadaannya harus dipelihara (hifd alnafs), sebagaiman firman Allah dalam al-Qur'an Surat (Q.S Al-Isra'/15 :33) yaitu membunuh orang hanya dibolehkan karena ada alasan yang benar, misalnya qishas bagi orang yang terbukti membunuh orang lain dengan sengaja.

b) Pengamanan hak milik pribadi (Q.S. AlBaqarah/2 :181).

c) Keamanan dan kesucian kehidupan pribadi (Q.S. An-nur/24 :27)

d) Hak untuk memperoleh keadilan hukum (Q.S. :)

e) Hak untuk menolak kezhaliman (Q.S. AnNisa'/4 :148)

f) Hak untuk melakukan al-amru bi al-ma'ruf wa al-nahyu 'an al-munkar, yang didalamnya juga mencakup hak-hak kebebasan memberikan kritik (Q.S. Al-A'raf/7 :165 dan Q.S. AlBaqarah/2 :110).

g) Hak keamanan dari penindasan keagamaan. Banyak sekali ayat al-Qur'an yang melarang pemaksaan, saling bertikai karena perbedaan agama, salah satunya adalah (Q.S. Ali Imran/3:100 ).

h) Hak untuk tidak menerima tindakan apapun tanpa ada kejahatan yang dilakukannya. Dengan kata lain seorang harus dianggap tidak bersalah, jika ia belum terbukti melakukan kejahatan.

i) Hak memperoleh perlakuan yang sama dari negara dan tidak melebihkan seseorang atas orang lain (Q.S. Al-Qashash/28 :4). ${ }^{11}$

Begitu juga halnya dengan Sunnah Nabi. Nabi Muhammad saw telah memberikan tuntunan dan contoh dalam penegakkan dan perlindungan terhadap HAM. Hal ini misalnya terlihat dalam perintah Nabi yang menyuruh untuk memelihara hak-hak manusia dan hak-hak kemuliaan, walaupun

\footnotetext{
${ }^{11}$ Syekh Syukat Hussain.1996. Hak asasi Mausia Dalam Islam. Terjemahan Abdul Rahim C.N , Jakarta: Insani Press. h. 59.
} 
terhadap orang yang berbeda agama, melalui sabda beliau :

"Barang siapa yang menzalimi seseorang mu'ahid (seorang yang telah dilindungi oleh perjanjian damai) atau mengurangi haknya atau membebaninya di luar batas kesanggupannya atau mengambil sesuatu dari padanya dengan tidak rela hatinya, maka aku lawannya di hari kiamat." 12

Pengaturan lain mengenai HAM dapat juga dilihat dalam Piagam Madinah dan Khutbah Wada'. Adapun inti dari Piagam Madinah ini meliputi prinsip-prinsip persamaan, persaudaraan, persatuan, kebebasan, toleransi beragama, perdamaian, tolong menolong dan membela yang teraniaya serta mempertahankan Madinah dari serangan musuh $^{13}$.

\section{Penetapan Undang-undang No.26 Tahun 2000}

Sebagaimana telah dikemukakan sebelumnya, Undang-undang Nomor 26 tahun $2000^{14}$ tentang Pengadilan Hak Asasi Manusia, disamping memuat hukum acara yang berlaku khusus di pengadilan HAM (formal), juga memuat hukum materil yaitu berupa ketentuan pidana berkenaan dengan pelanggaran hak asasi manusia yang berat. ${ }^{15}$

Mengutip dari pendapatnya R.Wiyono, bahwa apa yang dimaksud dengan Pengadilan HAM adalah merupakan pengadilan khusus yang berada di bawah lingkungan Pengadilan Umum, dan memutuskan perkara-perkara yang berat.

Dengan demikian maka jelaslah bahwa apa yang dimaksud dengan Pengadilan HAM adalah Pengadilan yang berada di lingkungan Peradilan Umum yang hanya bertugas dan berwenang untuk memeriksa dan memutus perkara pelanggaran HAM yang berat saja.

Disebutkan dalam pasal 7 Undang-undang Nomor 26 tahun 2000 menjelaskan bahwa pelanggaran hak asasi manusia yang berat tersebut terdiri dari :

1. Kejahatan terhadap kemanusiaan

\section{Kejahatan Genosida}

\footnotetext{
${ }^{12}$ T. Muhammad Hasbi Ash Shiddieqy, Islam dan Hak Asasi Manusia, PT Pustaka Rizki Putra,Semarang, 1999, h. 23 .

${ }^{13}$ Eggi Sudjana, HAM dalam Perspektif Islam, Nuansa Madani, JAKarta, 2002. h.89.

${ }^{14}$ UU No. 26 Tahun 2000 ini disahkan pada tanggal 6 November 2000.

${ }^{15}$ Wiyono.R. Pengadilan Hak Asasi Manusia di Indonesia. Kencana Prenada Media Group. Jakarta.2006.h.9.
}

\section{Kejahatan terhadap kemanusian}

Kejahatan terhadap kemanusiaan yaitu salah satu perbuatan yang dilakukan sebagai bagian dari serangan yang meluas atau sistematik yang diketahuinya bahwa serangan itu ditujukan secara langsung kepada penduduk sipil yang berupa :

a. Pembunuhan, dengan rumusan delik sebagaimana Pasal 340 KUHP. ${ }^{16}$

b. Pemusnahan, yaitu meliputi perbuatan yang menimbulkan penderitaan yang dilakukan dengan sengaja, antara lain berupa perbuatan menghambat pemasokan barang makanan dan obat-obatan yang dapat menimbulkan pemusnahan pada sebagian penduduk.

c. Perbudakan, dalam ketentuan ini termasuk perdagangan manusia, khususnya perdagangan wanita dan anak-anak.

d. Pengusiran dan pemindahan penduduk secara paksa, yaitu pemindahan orang-orang secara paksa dengan cara pengusiran atau tindakan pemaksaan yang lain dari daerah dimana mereka bertempat tinggal secara sah, tanpa disadari alasan yang diijinkan oleh hukum internasional.

e. Perampasan kemerdekaan atau perampasan kebebasan fisik lain secara sewenang-wenang yang melanggar (asas-asas) ketentuan pokok hukum internasional.

f. Penyiksaan, yaitu sengaja melawan hukum menimbulkan kesakitan atau penderitaan yang berat baik fisik maupun mental, terhadap seorang tahanan atau seorang yang berada di bawah pengawasan dari pelaku, dan hal ini tidak termasuk kesakitan atau penderitaan yang melekat atau sebagai akibat dari sanksi yang sah.

g. Perkosaan, perbudakan seksual, pelacuran secara paksa, pemaksaan kehamilan, pemandulan atau sterilisasi secara paksa atau bentuk-bentuk kekerasan seksual lain yang setara. Yang dilakukan dengan ancaman kekerasaan atau

${ }^{16}$ Pasal 340 KUHP menyatakan bahwa : Barang siapa dengan sengaja dan dengan direncanakan terlebih dahulu menghilangkan nyawa orang lain, karena salah telah melakukan pembunuhan dengan direncanakan terlebih dahulu, dihukum dengan hukuman mati atau dengan hukuman penjara seumur hidup atau dengan hukuman penjara sementara selama-lamanya 20 tahun. Ketentuan yang digunakan sebagai acuan adalah ketentuan deliknya dan bukan termasuk ancaman hukumannya karena ancaman hukuman dalam kejahatan terhadap kemanusiaan dalan UU No. 26 Tahun 2000 diatur tersendiri. 
penggunaan paksaan seprti ketakutan akan kekerasanm dibawah paksaanm penahanan tekananan psikologis atau penyalahgunaan kekuasaan dengan mengambil keuntungan dari keadaan yang dilakukan terhadap orang yang tidak mampu memberi persetujuan.

h. Penganiayaan terhadap suatu kelompok tertentu atau perkumpulan yang didasari persamaan paham politik, ras, kebangsaan, etnis, budaya, agama, jenis kelamin atau alasan lain yang telah diakui secara universal sebagai hal yang dilarang menurut hukum internasional.

i. Penghilangan orang secara paksa, yaitu penangkapan, penahanan, atau penculikan seseorang oleh atau dengan kuasa, dukungan atau persetujuan dari negara atau kebijakan organisasi, diikuti oleh penolakan untuk mengakui perampasan kemerdekaan tersebut, dengan maksud untuk melepaskan dari perlindungan hukum dalam jangka waktu yang panjang.

j. Kejahatan apartheid, yaitu perbuatan tidak manusiawi dengan sifat yang sama dengan sifat-sifat yang disebutkan dalam Pasal 8 yang dilakukan dalam konteks suatu rezim kelembagaan berupa penindasan dan dominasi oleh suatu kelompok rasial atas suatu kelompok atau kelompok-kelompok ras lain dan dilakukan dengan maksud untuk mempertahankan rezim itu. ${ }^{17}$

Untuk membedakan antara "kejahatan terhadap kemanusiaan" yang dapat digolongkan sebagai "pelanggaran hak asasi manusia yang berat" sebagaimana yang diatur dalam KUHP, ditentukan oleh unsur-unsur sebagai berikut : ${ }^{18}$

1. Adanya serangan yang meluas atau sistimatis.

2. Diketahui bahwa serangan tersebut ditujukan secara langsung kepada penduduk sipil.

3. Serangan itu berupa kelanjutan kebijakan yang berhubungan dengan organisasi.

\footnotetext{
${ }^{17}$ Muladi, Mekanisme Domestik untuk Mengadili Pelanggaran HAM Berat melalui Sistem Pengadilan atas Dasar UU No. 26 Tahun 2000, Makalah dalam Diskusi Panel 4 bulan Pengadilan Tanjung Priok, Elsam, 20 Januari 2004. Lihat juga, Pengadilan Pidana bagi Pelanggar HAM Berat di Era Demokrasi, 2000, Jurnal Demokrasi dan HAM, Jakarta, hlm. 54. Lihat juga dalam www.elsam.or.id.(accessed, 3 December 2015)

${ }^{18}$ Abdullah Rozali dan Syamsir, "Perkembangan HAM dan Keberadaan Peradilan HAM di Indonesia", Ghalia Indonesia, Bogor Selatan.Agustus 2004. h.60.
}

Apabila kejahatan terhadap kemanusiaan yang dilakukan tidak memenuhi ketiga unsur tersebut diatas, maka perbuatan itu digolongkan sebgai tindak pidana biasa yang diatur dalam KUHP dan diperiksa dan diputus oleh Pengadilan Agama dan bukan oleh pengadilan Hak Asasi Manusia.

\section{Kejahatan Genosida}

Kejahatan Genosida merupakan perbuatan kejahatan yang dilakukan dengan maksud untuk menghancurkan atau memusnahkan seluruh atau sebagian kelompok bangsa, ras, kelompok etnis, kelompok agama.

Genosida atau genosid adalah sebuah pembantaian besar-besaran secara sistematis terhadap satu suku bangsa atau kelompok dengan maksud memusnahkan bangsa tersebut. Kata ini pertama kali digunakan oleh seorang ahli hukum polandia, Raphael Lemkin, pada tahun 1944 dalam bukunya Axis Rule in Occupied Europe yang diterbitkan di Amerika Serikat. Kata ini diambil dari bahasa Yunani genos yang berarti ras, bangsa atau rakyat dan sedangkan cide diambil dari bahasa Latin yang artinya pembunuhan. ${ }^{19}$

Genosida merupakan satu dari empat pelanggaran HAM berat yang berada dalam yurisdiksi International Criminal Court. Pelanggaran HAM berat lainnya ialah kejahatan terhadap kemanusiaan, kejahatan perang, dan kejahatan Agresi. $^{20}$

Menurut Statuta Roma ${ }^{21}$ dan UndangUndang no. 26 tahun 2000 tentang Pengadilan HAM, genosida ialah Perbuatan yang dilakukan dengan maksud untuk menghancurkan atau memusnahkan seluruh atau sebagian kelompok bangsa, ras, kelompok etnis, kelompok agama dengan cara membunuh anggota kelompok; mengakibatkan penderitaan fisik atau mental yang berat terhadap anggota kelompok; menciptakan kondisi kehidupan kelompok yang menciptakan kemusnahan secara fisik sebagian atau seluruhnya;

${ }^{19}$ www.wikipedia.com, Coining of the term of Genocide. http:/ / explodingproduce.com. Lihat juga,Gregory H.Stanton, "Genocide", http//www.sekitarkita.com. 2 Maret 2006. (accessed, 5 Desember 2015).

${ }^{20}$ Abidin,Zainal, "Pengadilan Hak Asasi Manusia di Indonesia":Kursus HAM untuk pengacara XI tahun 2007. Lembaga Studi dan Advokasi Masyarakat. www.elsam. or.id.Page.5.

${ }^{21}$ Yaitu Undang-undang pengadilan Kriminal International Rome. romefra.htm. 
melakukan tindakan mencegah kelahiran dalam kelompok; memindahkan secara paksa anak-anak dalam kelompok ke kelompok lain. ${ }^{22}$

Ada pula istilah genosida budaya yang berarti pembunuhan peradaban dengan melarang penggunaan bahasa dari suatu kelompok atau suku, mengubah atau menghancurkan sejarahnya atau meng-hancurkan simbol-simbol peradabannya, dengan cara :

a. Membunuh anggota kelompok;

b. Mengakibatkan penderitaan fisik atau mental yang berat terhadap anggota-anggota kelompok;

c. Menciptakan kondisi kehidupan kelompok yang akan mengakibatkan kemusnahan secara fisik baik seluruh atau sebagian;

d. Memaksakan tindakan-tindakan yang bertujuan mencegah kelahiran di dalam kelompok atau;

e. Memindahkan secara paksa anak-anak dari kelompok tertentu ke kelompok lain. ${ }^{23}$

Jika diuraikan, ketentuan tersebut terdiri dari beberapa unsur sebagai berikut :

1. Kebanyakan setiap perbuatan mengandung dengan cara :

a. Keinginan membunuh anggota kelompok;

b. Adanya penderitaan fisik atau mental yang berat terhadap anggota-anggota kelompok;

c. Menciptakan kondisi kelompok yang akan mengakibatkan kemusnahan secara fisik, baik seluruh atau sebagiannya;

d. Memkasakan tindakan-tindakan yang bertujuan mencegah kelahiran didalam kelompok atau memindahkan secara paksa anak-anak dan kelompok tertentu kekelompok lain. ${ }^{24}$

2. Adanya maksud untuk menghancurkan atau memusnahkan sebagian atau seluruh kelompok bangsa, ras, etnis, agama.

Penjelasan tersebut menyebutkan bahwa segala kejahatan yang berbentuk pemusnahan secara menyeluruh atau berkelompok akan mengakibatkan kejahatan genosida yang secara mutlak termasuk

\footnotetext{
${ }^{22}$ Rome Statute Of The International Criminal Court, Article 6,"Genocide". romefra.htm.

${ }^{23}$ Rome Statute Of The International Criminal Court, Article 4,"Genocide".

${ }^{24}$ Wiyono.R. "Pengadilan Hak Asasi Manusia di Indonesia". Kencana Prenada Media Group. Jakarta.2006.h.18.
}

dalam kejahatan berat dan keadilannya ditentukan oleh pengadilan Ad Hoc.

\section{Contoh Kejahatan HAM Berat}

Kita ambil contoh di negara Bosnia dan Herzegovina yang terjadi mengenai banyaknya korban Chauvinisme.

Bosnia dan Herzegovina adalah salah satu contoh paling tragis dalam sejarah umat manusia tentang betapa chauvinisme yang tidak terkendali mengakibatkan pem-bunuhan semena-mena oleh suatu komunitas. Karena selama ini, orang Serbia didorong oleh impian Chauvinistik seperti memandang kaum muslim Balkan sebagai tembok penghalang.

Dalam perang Balkan, antara 1921 dan 1914 dan tahun 1941 banyak kaum Muslim yang terbunuh dalam insiden Foca yang keji. ${ }^{25}$

\section{Pengaruh Politik dalam Pembentukan Pengadilan HAM}

Pengadilan HAM yang dibentuk khusus untuk memeriksa dan memutus perkara pelanggaran HAM yang berat yang dilakukan sebelum adanya UU No. 26 Tahun 2000 disebut juga dengan pengadilan Ad Hoc.

Hal inilah yang membedakan dengan pengadilan HAM permanen yang dapat memutus dan mengadili perkara pelanggaran HAM yang berat yang terjadi setelah diundangkannya UU No. 26 Tahun 2000.

Banyak kasus pelanggaran HAM yang berat terjadi di Indonesia, misalnya untuk kasus pelanggaran HAM di Tanjung Priok dan Timurtimur dapat diselesaikan melalui pengadilan HAM ad hoc ini. Sampai saat ini sudah berdiri pengadilan HAM ad hoc untuk kasus pelanggaran HAM yang berat yang terjadi di Timor-timur dan Tanjung Priok.

Pengalaman pengadilan HAM ad hoc menunjukkan bahwa penerapan ketentuan dalam UU No. 26 Tahun 2000 tidak dapat diaplikasikan secara konsekuen karena pengaturan yang lemah. Di samping itu terobosan hukum juga banyak dilakukan oleh majelis hakim yang menangani perkara pelanggaran HAM di Timor-timur ini.

Pengadilan HAM di Indonesia merupakan salah satu bagian dari Sistem Peradilan di Indonesia.

\footnotetext{
${ }^{25}$ Chandra, Muzaffar, Hak. Asasi Manusia Dalam Tata Dunia Baru, Menggugat Dominasi Global Barat, Mizan Pustaka, 1995.h.163.
} 
Pengadilan HAM memiliki tugas penting untuk membangun rasa kepercayaan rakyat Indonesia dan komunitas Internasional tentang kedaulatan dan kepastian hukum di Indonesia saat ini. Pengadilan merupakan pengantar dari peradaban, demokratisasi dan pembebasan. Proses pengadilan yang anggun dan kredibel akan mentransformasikan nilai-nilai kemanusiaan dan memberikan pesan pendidikan nurani bagi bangsa manusia. Proses peradilan merupakan interakasi naluri kemanusiaan dan akal sehat. Nilai kemanusiaan sebagai anugrah dari Allah Yang Maha Kuasa merupakan suatu yang sakral. Untuk itu, pengadilan di Indonesia harus mampu meningkatkan penghargaan terhadap martabat manusia, intefritas nasional dan kepercayaan Internasional. Eksistensi dan peran pengadilan HAM adalah menghargai nilai kemanusiaan, hakhak korban, hak-hak pelaku, sensitifitas sosial dan moralitas universal. ${ }^{26}$

Menurut UU tentang HAM, pelanggaran hak asasi manusia adalah setiap perbuatan seseorang atau kelompok orang, termasuk aparat negara baik disengaja maupun tidak disengaja atau kelalaian yang secara melawan hukum mengurangi, menghalangi, membatasi, dan atau mencabut hak asasi manusia seseorang atau kelompok orang yang dijamin oleh Undang-undang ini, dan tidak mendapatkan, atau dikhawatirkan tidak memperoleh penyelesaian hukum yang adil dan benar, berdasarkan mekanisme hukum yang berlaku. Sehingga dapat diketahui sejauh mana peran pemerintah terhadap kekerasan Hak asasi manusia.

\section{Dampak Perubahan Sosial Dari Proses Kejahatan HAM}

Negara dan bangsa ini memiliki sejarah yang panjang berkaitan dengan persoalan hak asasi manusia. Persoalan tersebut seakan-akan melekat dalam ingatan sosial masyarakat Indonesia. Seperti kasus yang menimpa atas terjadinya bencana Tanjung Priok, Trisakti, Lumpur Lapindo, berturut - turut menempati peristiwa yang akan terus mengendap sebagai ingatan sosial masyarakat. Namun ingatan tersebut coba dikaburkan oleh pihak tertentu. Pengaburan dilakukan dalam berbagai bentuk. ${ }^{27}$

\footnotetext{
${ }^{26}$ Wiyono.R. Pengadilan Hak Asasi Manusia di Indonesia.h.18.

${ }^{27}$ Seperti yang dikutip dalam web makalah Eka, https:/ / ekaeldoneris.wordpress.com/2010/ 01/ 24/23/.
}

Pertama, pengakuan sejarah versi penguasa orde baru saat itu tetap diakui kesahihannya dengan mengabaikan penderitaan korban.

Kedua, kesaksian korban tidak dapat dikonfrontasikan dengan pelaku kejahatan HAM.

Ketiga, ketiadaan pengakuan hukum terhadap korban sebagai korban sehingga korban mengalami pengorbanan kedua dan pelaku menikmati pengampunan (impunity). Ketiga cara tersebut dilakukan secara sistematis melalui proses yang tidak tersentuh hukum. ${ }^{28}$ Berbagai peristiwa yang diduga sebagai pelanggaran HAM di masa lalu merupakan peristiwa yang diakibatkan oleh adanya kekerasan struktural oleh penguasa melalui institusi negara. Kekerasan struktural tidak harus dalam bentuk fisik. Ia dapat diwujudkan karena sudah cukup dipersiapkan melalui media massa atau elektronik. ${ }^{29}$

Kasus Tanjung Priok, 27 Juli 1996, dan kerusuhan Mei 1998 merupakan contoh nyata untuk kekerasan struktural yang biasaya dilakukan oleh dilakukan oleh komandan suatu pasukan, keamanan atau pimpinan politik, polisi, para prajurit, orang-orang dilapangan atau pelaksana keamanan yang membiarkan terjadinya kejahatan yang dilakukan atau dibiarkan oleh otoritas negara untuk menimbulkan penderitaan fisik dan mental atas sekelompok masyarakat Indonesia.

Dapat disimpulkan bahwa karakteristik kekerasan struktural dapat terjadi dikarenakan sebagai berikut :

1. Berupa perbuatan fisik atau mental.

2. Dilakukan oleh otoritas, badan negara, perorangan atau golongan yang diberikan otoritas oleh negara.

3. Berupa melakukan atau membiarkan terjadinya kejahatan subkultur gerakan sosial - politik, yang dilakukan atau dibiarkan terjadi oleh badan negara.

4. Menimbulkan ketakutan serta penderitaan fisik maupun mental atas seseorang atau sekelompok orang. ${ }^{30}$

\footnotetext{
${ }^{28}$ Wiyono.R. Pengadilan Hak. Asasi Manusia di Indonesia. h.78.

${ }^{29}$ Sahetapy, Tempo :volume 31, masalah 48-52.

${ }^{30} \mathrm{http}: / /$ abimata.wordpress.com/2009/10/01/ pengaruh-politik-dalam-pembentukan pengadil-an- hamad-hoc/
} 


\section{Kesimpulan :}

Pertama, kekerasan struktural yang pernah terjadi di Indonesia merupakan pelanggaran HAM berat dikarenakan dalam penegakan hukum tidak memiliki kekuatan yang kuat.

Kedua, pengaruh politik dalam pembentukan pengadilan HAM ad - hoc untuk memeriksa dan mengadili serta memutus dugaan pelanggaran HAM berat sangat signifikan. Dibutuhkan dukungan dari berbagai golongan politik yang kuat untuk menuntaskan ingatan sosial yang kelam untuk memenuhi rasa keadilan korban dan masyarakat.
Ketiga, sifat pengaruh politik secara normatif dalam pembentukan pengadilan HAM ad - hoc berdasarkan UU tentang Pengadilan HAM adalah netral. Pelaksanaan ruang untuk pengaruh politik tergantung dari kebijakan penguasa.

Keempat, dampak perubahan dari ketentuan keadilan pelanggaran berat menimbulkan kegelisahan diantara masyarakat karena tidak adanya ketentuan yang jelas dalam pelaksanaannya.

\section{Lampiran Ketentuan Pemidanaan}

\begin{tabular}{|l|l|l}
\hline Kejahatan & $\begin{array}{l}\text { Hukuman } \\
\text { minimal }\end{array}$ & Hukuman maksimal \\
\hline Genosida & 10 tahun & $\begin{array}{l}\text { Mati atau seumur hidup atau } \\
\text { penjara paling lama 25 tahun }\end{array}$ \\
\hline
\end{tabular}

Kejahatan terhadap kemanusiaan, berupa :

\begin{tabular}{|l|l|l|}
\hline a. Pembunuhan & 10 tahun & $\begin{array}{l}\text { Mati atau seumur hidup atau } \\
\text { penjara paling lama 25 tahun }\end{array}$ \\
\hline b. Pemusnahan & 10 tahun & $\begin{array}{l}\text { Mati atau seumur hidup atau } \\
\text { penjara paling lama } 25 \text { tahun }\end{array}$ \\
\hline c. Perbudakan & 5 tahun & 15 tahun \\
\hline $\begin{array}{l}\text { d. Pengusiran atau pemindahan penduduk } \\
\text { secara paksa }\end{array}$ & 10 tahun & $\begin{array}{l}\text { Mati atau seumur hidup atau } \\
\text { penjara paling lama } 25 \text { tahun }\end{array}$ \\
\hline $\begin{array}{l}\text { e. Perampasan kemerdekaan atau perampasan } \\
\text { kebebasan fisik secara sewenang-wenang } \\
\text { yang melanggar (asas-asas) ketentuan } \\
\text { pokok hukum internasional }\end{array}$ & 10 tahun & $\begin{array}{l}\text { Mati atau seumur hidup atau } \\
\text { penjara paling lama } 25 \text { tahun }\end{array}$ \\
\hline f. Penyiksaan & 5 tahun & 15 tahun \\
\hline $\begin{array}{l}\text { g. Perkosaan, perbudakan seksual, pelacuran } \\
\text { secara paksa, pemaksaan keHAMilan, } \\
\text { pemandulan atau sterilisasi, secara paksa } \\
\text { atau bentuk-bentuk kekerasan seksual } \\
\text { lainnya yang setara }\end{array}$ & 10 tahun & 20 tahun \\
\hline $\begin{array}{l}\text { h. Penganiayaan terhadap suatu kelompok } \\
\text { tertentu atau perkumpulan yang didasari } \\
\text { persamaan paHAM politik, ras, kebangsaan, } \\
\text { etnis, budaya, agama, jenis kelamin atau } \\
\text { alasan lain yang telah diakui secara universal } \\
\text { sebagai hal yang dilarang menurut hukum } \\
\text { internasional }\end{array}$ & 10 tahun & 20 tahun \\
\hline
\end{tabular}




\begin{tabular}{|l|l|l|}
\hline i. Penghilangan orang secara paksa & 10 tahun & 20 tahun \\
\hline j. Kejahatan apartheid & 10 tahun & $\begin{array}{l}\text { Mati atau seumur hidup atau } \\
\text { penjara paling lama } 25 \text { tahun }\end{array}$ \\
\hline $\begin{array}{l}\text { Percobaan, permufakatan jahat, atau } \\
\text { pembantuan untuk melakukan pelanggaran } \\
\text { kejahatan terhadap kemanusiaan }\end{array}$ & $\begin{array}{l}\text { Dipersamakan } \\
\text { dengan } \\
\text { ketentuan di } \\
\text { atas sesuai } \\
\text { dengan } \\
\text { bentuk } \\
\text { kejahatannya }\end{array}$ & $\begin{array}{l}\text { Dipersamakan dengan } \\
\text { ketentuan di atas sesuai } \\
\text { dengan bentuk kejahatannya }\end{array}$ \\
\hline $\begin{array}{l}\text { Komandan militer, polisi dan atasan sipil yang } \\
\text { melakukan kejahatan terhadap kemanusiaan } \\
\text { dan kejahatan genosida }\end{array}$ & $\begin{array}{l}\text { Dipersamakan } \\
\text { dengan } \\
\text { ketentuan di } \\
\text { atas sesuai } \\
\text { dengan } \\
\text { bentuk } \\
\text { kejahatannya }\end{array}$ & $\begin{array}{l}\text { Dipersamakan dengan } \\
\text { dengan bentuk kejahatannya }\end{array}$ \\
\hline
\end{tabular}

\section{DAFTAR PUSTAKA}

Abdulla Rozali, "Perkembangan HAM dan Keberadaan Pengadilan HAM di Indonesia", Ghalia Indonesia, Jakarta.

Abdullah Rozali dan Syamsir, "Perkembangan HAM dan Keberadaan Peradilan HAM di Indonesia", Ghalia Indonesia, Bogor Selatan.Agustus 2004.

Gregory H.Stanton, "Genocide", http//www. sekitarkita.com. 2 Maret 2006. (accessed, 5 Desember 2010).

Jurnal Demokrasi dan HAM Pengadilan Pidana bagi Pelanggar HAM Berat di Era Demokrasi, 2000, Jakarta.www.elsam.or.id.(accessed, 3 December 2010)

Kamil,Sukron dkk, "Syariah Islam dan HAM", Center for the Study of Religion and Culture (CSRC) Universitas Islam Negeri Syarif Hidayatullah Jakarta.2007.
Muladi, Mekanisme Domestik untuk Mengadili Pelanggaran HAM Berat melalui Sistem Pengadilan atas Dasar UU No. 26 Tahun 2000, Makalah dalam Diskusi Panel 4 bulan Pengadilan Tanjung Priok, Elsam, 20 Januari 2004.

Rome Statute Of The International Criminal Court, romefra.htm.

Tim ICCE, "Pendidikan Kewarganegaraan: Demokrasi, HAM, dan Masyarakat Madani”, Jakarta, 2003.

Timur.M. "Hak asasi manusia dalam Islam", sebuah dialog tentang Islam dan hak-hak asasi manusia. Yayasan Obor Indonesia, Jakarta 1987.

Wiyono.R. "Pengadilan Hak Asasi Manusia di Indonesia”. Kencana Prenada Media Group. Jakarta.2006.

Zainal Abidin,"Pengadilan Hak Asasi Manusia di Indonesia":Kursus HAM untuk pengacara XI tahun 2007. Lembaga Studi dan Advokasi Masyarakat. www.elsam.or.id. 